\title{
ОСОБЛИВОСТІ ПРОЯВІВ БОЙОВИХ СТРЕСОВИХ РОЗЛАДІВ У ПОРАНЕНИХ ВІЙСЬКОВОСЛУЖБОВЦІВ ЗБРОЙНИХ СИЛ УКРАЇНИ - УЧАСНИКІВ БОЙовИХ ДІЙ
}

\author{
Л. В. Радецька, І. О. Лаба, А. І. Смачило, О. О. Нечаєва, \\ К. О. Лопатенко, М. М. Баумер \\ Тернопільський національний медичний університет \\ імені І. Я. Горбачевського МОЗ Украӥни
}

\begin{abstract}
Рання діагностика негативних психічних і постстресових станів дозволяє на ранніх етапах виявити у поранених військовослужбовців Збройних сил України ранні та тяжкі прояви бойової психічної травми та її наслідки, а також розробити індивідуальну тактику і способи профілактики та відновлення кожного обстеженого військовослужбовця. Відсутність у державі єдиного, науково обгрунтованого комплексного підходу до організації проведення ефективних заходів медичної, психологічної та соціальної реабілітації, гостра потреба у підвищенні якості життя, медичного обслуговування, соціального захисту та медикопсихологічної допомоги військовослужбовцям зумовили актуальність дослідження, метою якого стало вивчення особливостей проявів бойових стресових розладів серед військовослужбовців Збройних сил України - учасників бойових дій. У процесі роботи виявлено, що участь у збройному конфлікті, отримане поранення $€$ потужним стресовим фактором, що призводить до різнопланових функціональних порушень організму, в тому числі й психологічних. При вивченні таких змін у значної частини військовослужбовців, які отримали поранення, виявлено ознаки посттравматичної стресової реакції. Відповідно дана категорія пацієнтів потребує як медичної, так і психологічної реабілітації.
\end{abstract}

\section{PECULIARITIES OF MANIFESTATIONS OF COMBAT STRESS DISORDERS IN WOUNDED SOLDIERS OF THE ARMED FORCES OF UKRAINE - COMABTANTS}

\author{
L. V. Radetskaya, I. O. Laba, A. I. Smachylo, O. O. Nechaeva, \\ K. O. Lopatenko, M. M. Baumer
}

\section{Horbachevsky Ternopil National Medical University}

\begin{abstract}
Early diagnosis of negative mental states, post-stress states allows detecting early and severe manifestations of combat mental trauma and its consequences in wounded servicemen of the Armed Forces of Ukraine, and also allows developing individual tactics and methods of prevention and recovery of each examined serviceman. The lack of a unified, scientifically sound comprehensive approach to the organization of effective measures of medical, psychological and social rehabilitation, the urgent need to improve the quality of life, medical care, social protection and medical and psychological assistance to servicemen, led to the urgency of the study. Disorders among servicemen of the Armed Forces of Ukraine - participants in hostilities. In the course of work it is revealed that participation in the armed conflict, the received wound is a powerful stress factor leading to various functional disturbances of the body, including psychological. When studying such changes in servicemen who were injured, a significant part of them showed signs of post-traumatic stress response. Accordingly, this category of patients needs both medical and psychological rehabilitation.
\end{abstract}

Вступ. 3 початку тимчасової окупації Російською Федерацією Автономної Республіки Крим та розпалювання збройного конфлікту в східних регіонах України, згідно зі статичними даними, отриманими від Міністерства у справах ветеранів, станом на 1 липня
2019 р. нараховують майже 370 тис. осіб, які отримали статус учасника бойових дій із числа осіб, які захищали незалежність, суверенітет та територіальну цілісність України [1]. Дані наукових літературних джерел свідчать про те, що кожен п'ятий учасник бойових 
дій, навіть при відсутності фізичної травми, страждає від нервово-психічних розладів, а через декілька місяців після повернення до нормальних умов життя у нього проявляються інші наслідки - різноманітні психосоматичні захворювання $[1,5,6,10]$.

Одним із клінічних видів бойової психічної патології $\epsilon$ посттравматичний стресовий розлад (ПТСР), який може виникати в учасників бойових дій через будь-який чітко не встановлений проміжок часу після впливу травмувального фактора (від декількох місяців до декілька десятків років). Відповідно до МКX-10, ПТСР належить до числа психогенних захворювань, що зумовлені впливом неординарного, надзвичайного стресу, який може викликати дистрес у будь-якої людини. У багатьох дослідженнях констатують той факт, що посттравматичні стресові розлади можуть складати від 10 до 50 \% усіх медичних наслідків бойових дій [4, $6,9]$. До змінених психічних станів, що можуть виникати у військовослужбовців у період ведення бойових дій, відносять: бойову стресову реакцію (початковий прояв дезадаптаційних розладів), бойову втому та посттравматичний стресовий розлад, а також реактивні стани як найтяжчі форми бойової психіатричної патології [5, 6]. У результаті такого значного негативного впливу факторів бойової діяльності, близько 90 \% військовослужбовців потребують комплексної медичної реабілітації, що стає пріоритетом державної соціальної політики та складовою медичної реформи на сучасному етапі $[2,4,7,8]$.

Мета роботи - дослідити особливості проявів бойових стресових розладів серед військовослужбовців Збройних сил України - учасників бойових дій з метою обґрунтування удосконалення системи медичної реабілітації військовослужбовців на регіональному рівні.

Основна частина. Дослідження проводили серед пацієнтів Комунального некомерційного підприємства «Обласний клінічний госпіталь ветеранів війни Кіровоградської обласної ради». Діагностику виду і рівня психологічних наслідків участі поранених у бойових діях, вибір необхідних реабілітаційних заходів та їх психологічну реабілітацію проводили відповідно до наказу Міністерства оборони України від 09.12.2015 р. № 702 «Про затвердження Положення про психологічну реабілітацію військовослужбовців Збройних сил України, які брали участь в антитерористичній операції, під час відновлення боєздатності військових частин (підрозділів)» [4], а також Уніфікованого клінічного протоколу первинної, вторинної (спеціалізованої) та третинної (високоспеціалізованої) медичної допомоги «Реакція на важкий стрес та розлади адаптації. Посттравматичний стресовий розлад» [5].

Для дослідження психологічного стану військовослужбовців, які після отримання поранення перебували на стаціонарному лікуванні у Військово-медичному клінічному центрі Західного регіону, як діагностичний психологічний тест використано Коротку шкалу тривоги, депресії та ПТСР [3]. Дана діагностична методика $\epsilon$ однією з методик, рекомендованих Науково-діагностичним центром гуманітарних проблем Збройних сил України для застосування з метою діагностики негативних психічних станів військовослужбовців, які перебували в районі ведення бойових дій [3]. Коротка шкала тривоги, депресії та ПТСР призначена для первинного скринінгу перерахованих симптомів у осіб, які пережили різного виду психічні травми.

Обробка результатів, отриманих після проведення тестування за Короткою шкалою тривоги, депресії та ПТСР, полягала в підрахунку кількості позитивних відповідей: чим більше відповідей «так» дає респондент, тим більш виражені у нього негативні психологічні наслідки травматизації, такі як тривога і депресія, що вважають найбільш специфічними проявами ПТСР. «Пороговим» значенням для визначення наявності порушень психічного стану $є$ більше 4 відповідей «Tак».

Крім цього, з кожним із поранених проводили психологічну бесіду (клінічне інтерв'ю). Дану методику застосовували з метою вивчення психологічного стану військовослужбовця після отримання ним поранення. Вона ґрунтується на вербальній соціально-психологічній взаємодії між психологом та пораненим, з яким проводять бесіду. Це дає можливість шляхом постановки під час бесіди спрямованих запитань виявити в учасника бойових дій такі психологічні розлади, як перебільшене реагування, агресивність, порушення пам'яті та концентрації уваги, депресія, тривожність, галюцинації, проблеми зі сном (тяжкість засипання, переривчастий сон).

Психологічне обстеження з використанням вищеперерахованих методик проведено серед 55 поранених, які перебували на лікуванні у Комунальному некомерційному підприємстві «Обласний клінічний госпіталь ветеранів війни Кіровоградської обласної ради».

Усі пацієнти, які перебували під спостереженням, отримали поранення в зоні проведення антитеро- 
ристичної операції. Вік пацієнтів коливався від 20 до 52 років, середній вік становив $(34,9 \pm 2,1)$ року. Поділ поранених за віком наведено в таблиці 1.

Таблиця 1. Вікова характеристика досліджуваних військовослужбовців

\begin{tabular}{|c|c|}
\hline Вік поранених, роки & Вікова структура, \% \\
\hline $20-30$ & 35,9 \\
\hline $31-40$ & 31,6 \\
\hline $41-50$ & 26,9 \\
\hline $51-60$ & 4,6 \\
\hline Всього & 100 \\
\hline
\end{tabular}

Поділ пацієнтів за характером отриманих поранень наведено в таблиці 2.

Таблиця 2. Поділ пацієнтів за характером травми

\begin{tabular}{|l|c|}
\hline \multicolumn{1}{|c|}{ Характер травми } & Кількість пацієнтів, n (\%) \\
\hline Вогнепальне поранення & $31(56,4)$ \\
\hline Мінно-вибухове поранення & $22(40,0)$ \\
\hline Термічне поранення & $2(3,6)$ \\
\hline Всього & $55(100)$ \\
\hline
\end{tabular}

Як видно з наведених у таблиці 2 даних, більшість поранених (31 пацієнт (56,4 \%)) отримали вогнепальне поранення; мінно-вибухову травму - 22 пацієнти (40,0 \%); термічну травму - 2 пацієнта (3,6 \%).

Структура поранень обстежених пацієнтів наведена в таблиці 3, згідно з даними якої у структурі поранень серед обстеженої категорії осіб переважали поранення нижніх кінцівок у 19 пацієнтів (34,6 \%); поранення верхніх кінцівок - в 12 пацієнтів (21,0%); поранення грудної клітки - у 5 пацієнтів (9,9%); поранення живота - в 4 пацієнтів $(6,1 \%)$; поранення голови - у 7 пацієнтів (11,9\%), закрита черепно-мозкова травма - в 3 пацієнтів (4,7 \%); поранення хребта - у одного пацієнта (1,4\%); поєднані поранення - в 6 пацієнтів (10,4\%).

Таблиця 3. Структура пацієнтів за локалізацією поранення

\begin{tabular}{|l|c|}
\hline \multicolumn{1}{|l|}{ Локалізація поранення } & Структура пацієнтів, \% \\
\hline Нижні кінцівки & 34,6 \\
\hline Верхні кінцівки & 21,0 \\
\hline Грудна клітка & 9,9 \\
\hline Живіт & 6,1 \\
\hline Голова & 11,9 \\
\hline $\begin{array}{l}\text { Закрита черепно-мозкова } \\
\text { травма }\end{array}$ & 4,7 \\
\hline Поранення хребта & 1,4 \\
\hline Поєднані поранення & 10,4 \\
\hline Всього & 100 \\
\hline
\end{tabular}

На основі аналізу результатів психологічного обстеження поранених встановлено наступне. Серед 55 обстежених у 21 пацієнта (38,8 \%) виявлено ознаки
ПТСР, а в 34 пацієнтів (61,2 \%) - не виявлено. Отримані нами результати цілком відповідають даним наукової літератури - у 25 \% військовослужбовців, які брали участь у бойових діях і не отримали поранення, виникають психологічні розлади [3, 4]. Серед поранених та тих, хто отримав інвалідність внаслідок поранення, даний синдром спостерігають набагато частіше і він сягає 40-50\% [7].

За результатами тестування встановлено, що серед 21 пацієнта, у яких діагностовано ПТСР, у 6 (28 \%) при підрахунку результатів кількість позитивних відповідей, отриманих під час первинного скринінгу за Короткою шкалою тривоги, депресії та ПТСР, значно перевищувала «порогове» значення. Обробка отриманих результатів (відповідно до інструкції) полягала в підрахунку кількості позитивних відповідей: чим більше відповідей «так» дає респондент, тим більш виражені у нього негативні психологічні наслідки травматизації, такі як тривога і депресія, що $\epsilon$ найбільш специфічними проявами ПТСР. «Пороговим» значенням для визначення наявності порушень психічного стану $є$ більше 4 відповідей - «так».

321 опитаного пацієнта 10 (47,9 \%) відповіли «так» на дев'ять запитань. На сім запитань відповіли «так» 5 осіб (22,8 \%), 3 (15,9\%) - на шість запитань та 2 (13,4 \%) - на п'ять запитань, що також перевищує «порогове» значення при визначенні наявності порушень психічного стану.

Наявність у 21 пораненого ознак ПТСР підтверджують і результати проведеної з ними психологами психодіагностичної бесіди (клінічного інтерв'ю). Аналіз отриманих результатів дозволив виділити наступні групи психологічних ознак ПтСР у обстежених поранених. Серед ознак порушення психологічного стану більшість поранених (46 \%) скаржилась на порушення сну. Питома вага інших порушень психологічного стану в поранених із ПтСР розподілилась наступним чином: 33 \% скаржились на емоційну нестійкість; 32 \% - дратівливість, підвищену емоційність; 28 \% нездатність розслабитись; 25 \% - погану концентрацію уваги; 19 \% - погіршення пам'яті; 10 \% - замкнутість, байдужість; $11 \%$ - пригнічений настрій.

Серед 21 пораненого, у якого, за даними тестування за Короткою шкалою тривоги, депресії та ПтСР, не було діагностовано ПТСР, результати розподілились таким чином. Більшість опитаних даної категорії 39 пацієнтів (58,2 \%) - дали відповідь «так» на три запитання, 21 пацієнт (31,3 \%) відповів «так» на два запитання, 7 (10,4 \%) - на два запитання. Це і стало 
підставою для припущення відсутності у них ознак ПТСР, оскільки у жодного із 67 поранених не було відзначено перевищення «порогового» значення позитивних відповідей.

Однак необхідно зазначити, що під час проведення психологом з ними психодіагностичної бесіди (клінічного інтерв'ю), в усіх поранених все ж таки були скарги (групи психологічних ознак), що свідчать про зміни психологічного стану, однак не $\in$ достатніми для підтвердження наявності ознак ПТСР. Серед них переважали скарги на порушення сну; наявність дратівливості, підвищеної агресивності.

Відсутність ознак ПтСР у 34 осіб з 55 обстежених поранених можливо пов'язано з тим, що у певної категорії військовослужбовців психологічні наслідки перебування на війні, отримання поранення можуть проявлятись не відразу після повернення до мирного життя, а лише через деякий час. Тобто у них розвивається один із варіантів ПТСР - віддалений ПТСР. При такій формі ПТСР симптоми стресового розладу відсутні протягом 6 місяців після отримання психологічної чи фізичної травми $[9,10]$.

\section{СПИСОК ЛІТЕРАТУРИ}

1. URL : zakon.rada.gov.ua/laws/show/700-2019$\%$ D0\%BF\#Text.

2. Голяченко А. О. Соціально-медичні та економічні аспекти організації системи медичної реабілітації в умовах реформування охорони здоров'я в Україні : автореф. дис. на здобуття наук. ступеня доктора мед. наук : 14.02.03 / А. О. Голяченко. - К., 2008. - 36 с.

3. Збірник методик для діагностики негативних психічних станів військовослужбовців : методичний посібник / Н. А. Агаєв, О. М. Кокун, І. О. Пішко [та ін.]. - К. : НДЦ ГП 3СУ, 2016. - 234 c.

4. Про затвердження Положення про психологічну реабілітацію військовослужбовців Збройних сил України, які брали участь в антитерористичній операції, під час відновлення боєздатності військових частин (підрозділів) : наказ Міністерства оборони України від 09.12.2015 р. № 702 [Електронний ресурс] // Офіційний сайт Верховної Ради України. - Режим доступу : http://zakon3.rada.gov.ua/ laws/show/z0237-16/card2\#Card.

5. Радиш Я. Ф. Медична реабілітація військовослужбовців як наукова проблема: теоретико-методологічні засади (за матеріалами літературних джерел) / Я. Ф. Радиш, О. М. Соколова // Економіка та держава. - 2012. № 3. - С. 103-106.
Американські автори, які проводили дослідження в різні періоди часу після закінчення війни у В'єтнамі, вказали на значну кількість ветеранів, які потребували спеціалізованої медичної допомоги та соціальномедичної реабілітації [10]. Так, через 5 років після закінчення війни кількість їх склала 250 тис. чоловік. Через 7 років після війни в літературі з'явились повідомлення про серйозні проблеми, пов'язані з порушенням адаптації до мирного життя, вже у 500 тис. ветеранів. Ці проблеми визначалися як відстрочені реакції на стрес, перенесений під час війни $[9,10]$.

Висновки. 1. Участь у збройному конфлікті, отримане поранення $є$ потужним стресовим фактором, що призводить до різнопланових функціональних порушень організму, в тому числі й психологічних.

2. При вивченні психологічних змін у військовослужбовців, які отримали поранення, встановлено, що в 38,8 \% обстежених пацієнтів виявлено ознаки посттравматичної стресової реакції.

3. Дана категорія пацієнтів потребує як медичної, так і психологічної реабілітації.

6. Єна А. І. Актуальність і організаційні засади медикопсихологічної реабілітації учасників антитерористичної операції / А. І. Єна, В. В. Маслюк, А. В. Сергієнко // Науковий журнал МОЗ України. - 2014. - № 1 (5). - С. 5-16.

7. Бриндіков Ю. Л. Реабілітація військовослужбовців учасників бойових дій в системі соціальних служб: теоретико-методичні основи : монографія / Ю. Л. Бриндіков. - Хмельницький : Вид-во «Поліграфіст», 2018. - 372 с.

8. Буряк О. О. Військовий синдром «АТО»: актуальність та шляхи вирішення на державному рівні / О. О. Буряк, М. І. Гіневський, Г. Л. Катеруша // Збірник наукових праць Харківського національного університету Повітряних Сил. - 2015. - № 2 (43). - С. 176-181.

9. Meyers L. L. Service utilization following participation in cognitive processing therapy or prolonged exposure therapy for post-traumatic stress disorder / L. L. Meyers, T. Q. Strom, J. Leskela [et al.] // Military Medicine. - 2013. Vol. 178 (1). - P. 95-99.

10. McNally R. J. Association of intelligence with severity of posttraumatic stress disorder symptoms in Vietnam Combat veterans / R. J. McNally, L. M. Shin // Am. J. Psychiatry. - 1995. No. 152. - P.936-938. 